\title{
THE AMERICAN INTERPRETATION OF THE "MOST FAVORED NATION" CLAUSE
}

By Chester Lloyd Jones, Ph.D., Instructor in Political Science, University of Pennsylvania, Philadelphia.

The navigation legislation of the United States has been of varied and apparently contradictory character. Often, however, the laws passed have been inconsistent only in effect while prompted by the same general motives. A large portion of our early legislation as to tonnage dues, for example, was passed not to further the development of the American marine alone, nor to furnish revenue for the government, but with the object of forcing other countries to grant fair conditions of commerce. Our earliest agreements with foreign nations show a desire to give and accord the most liberal terms for international trade. Shortly after the ratification of the constitution, however, a severe policy of discrimination against foreign shipping was adopted resulting in the series of "countervailing" tonnage laws by which England and the United States piled restriction after restriction on colonial commerce, one aiming to force the other to open its West Indian markets, the other striving to keep all the trade under its antiquated system of navigation laws. All this was an attempt to force what we considered fair conditions of trade-an attempt wholly opposed in its effect to the general result which the United States sought to secure, the establishment of a free field for competition in the colonial markets. With the second third of the nineteenth century a more liberal policy saw the abolition of many of the navigation restrictions, and until the Civil War brought the re-enactment of tonnage dues there was a period in which comparatively little discriminatory tonnage legislation was passed. The necessity of an increased income during the Civil War brought the renewed levy of tonnage duties which, through a combination of reasons, continue even to-day, as will be shown.

Our commercial legislation, except as discriminations have been 
made to favor our own merchants, has been uniformly in support of equal terms to all nations. There has been no granting of special unrequited advantages in trade to certain nations. We have endeavored to grant and secure equal opportunity in all markets to all nations.

Most favored nation agreements have been a factor in the treaty making of the United States from the beginning of our international relations. The very first of our commercial treaties, that of 1778 , with France, though falling short of obtaining the unrestricted trade arrangements for which the negotiators argued, secured at least the guarantee that there should be no discrimination in French ports against the products of the United States as contrasted with other countries. The principle thus early introduced appears frequently in our subsequent treaties, and with us as with nations in general has become from the '7o's on, a regular feature of international conventions.

Of late years our efforts to establish equal opportunity in international commerce have extended beyond the scope of treaty-making in the narrow sense. Our stand for the open door in the Far East is in fact but another manifestation of the same policy. It is the attempt to assure not only fair conditions in trade with the powers with whom we have direct treaty relations, but to guarantee that none of the great powers shall by agreements with the weaker nations of the Orient obtain any right which shall be prejudicial to the commercial interests of other nations similarly situated. The part the United States has played in the world politics of the Far East has been controlled by the old desire to prevent the monopolization of the trade of certain districts-to prevent a recrudescence of commercial policies similar to those which flourished in the eighteenth century and which the first half of the nineteenth century outgrew.

This policy of equal opportunity for all does not attempt in the least to limit the right of each nation to determine for itself its own fiscal policy, indeed, especially as it shows itself in the Far East it works rather to guarantee to each nation the freedom to discriminate against foreigners. The end sought is rather to assure that to single nations no advantage shall be granted which shall not be granted to other nations upon the grant of equivalent favors. The "most favored nation" principle, in other words, does not at 
all interfere with the reciprocity agreements. It allows the nations to contract for mutual concessions with as much freedom as ever.

\section{Interpretation of the Clause in Reciprocity Treaties}

In spite of the apparent simplicity of this principle, conflict has repeatedly arisen as to the proper interpretation of the "most favored nation" guarantees. The point which is the subject of contention usually narrows down to this: When nation A grants special terms to nation $B$ as to the importation of certain articles in return for concessions by nation $B$ on certain points, does that give all other nations with the "most favored nation" clause in their treaties the right to demand the same concessions upon their declaring their willingness to yield the same points yielded to nation $B$. Is it permissible, on the other hand, to maintain that the grant to nation $B$ for the return of special concessions gives the other nations only the right to demand a similar grant when they have themselves made concessions which the treaty-making power of nation A shall consider the equivalent of those made by nation B? Suppose, for example, that the United States should grant specially low duties on French dry-goods in return for low duties on American agricultural machinery. Is it open to Germany to demand the same terms for her dry-goods under her "most favored nation" treaty upon the tender of the same terms on imports of American agricultural machinery, or may the United States contend that the grant of low duties to German dry-goods would be more than an equivalent return, and would therefore place Germany not on the general basis of the most favored nation (presumably in this case, France), but would make her an especially favored nation, thus, in fact, violating the very principle which the "most favored nation" clause was intended to guarantee? In other words, are reciprocity agreements to be considered as automatically extending to all nations with "mast favored nation" clauses in their treaties, or must each be the subject of a special negotiation, a special bargain between the countries involved, except where the favors are freely granted?

In this controversy practically all the important nations of Europe have adopted the first view, the United States has from the beginning contended for the second in spite of the apparently con- 
tradictory language of many of its treaties. The most important country which stands with the United States on this point is Japan.

\section{The American Position}

Though the conflict as to the interpretation of the meaning of the "most favored nation" clause did not arise in the United States till almost thirty years later, and then in connection with a subsequent treaty, the commercial treaty of 1788 with France states what has been the consistent American understanding. It declares that "the most Christian King and the United States engage mutually not to grant any particular favor to other nations in respect of commerce and navigation which shall not immediately become common to the other party who shall enjoy the same favor freely if the concession was freely made, or on allowing the same compensation if the concession was conditional." The words "same compensation," or the similar phrases which take their place in other treaties have been consistently interpreted by our government to mean "same in amount," or "equivalent," not "concessions on the same classes of articles."

What is the character of the concessions which will be considered an equivalent is to be left entirely to the treaty-making powers of the respective states. The mutual concessions are "to be honorably determined by the governments concerned." In binding itself to grant the "most favored nation" treatment a government does not bind itself to any definite program. It only pledges its honor that it will not adopt a conscious policy of discrimination. Special privileges in relation to customs on certain articles may be given, or the use of a port as a coaling station, the grant of a protectorate, in fact, anything within the scope of the treaty-making power may be the subject of the concession, and such special privilege granted for a special return is not to be considered as a discrimination which would justify other powers in complaining. They may not enjoy as a right or for a lesser payment a privilege for which other countries have given a valuable equivalent.

This uniform holding by the executive departments was further strengthened by a decision of the Supreme Court in 1887 . The question involved was whether Denmark, under its "most favored nation" treaty with the United States, could claim that sugar from the Danish Island of St. Croix should be admitted to the United (386) 
States free of duty because a recent treaty had granted that privilege to Hawaiian sugar. The decision of the court is given as follows :

"Our conclusion is that the treaty with Denmark does not bind the United States to extend to that country without compensation privileges which they have conceded to the Hawaiian Islands in exchange for valuable concessions."1

The last important statements concerning the meaning of this clause in its application to reciprocity treaties were made in the discussions arising under the Dingley Tariff Act of 1897 . In explaining the position of the United States, Secretary Sherman, in a letter to Mr. Buchanan, Minister of the United States to Argentina, stated:

"It is clearly evident that the object sought in all the varying forms of expression is equality of international treatment, protection against the wilful preference of the commercial interests of one nation over another. But the allowance of the same privileges and the same sacrifice of revenue duties to a nation which makes no compensation that had been conceded to another nation for an adequate compensation instead of maintaining destroys that equality, which the 'most favored nation' clause was intended to secure. It concedes for nothing to one friendly nation that which the other gets only for a price." . . . "The right of the other nations to enjoy the same special concessions depends on their ability to offer an equivalent compensation. When they do this the "favored nation clause' is rightly invoked."2 Even when the second nation offers the same nominal concessions as given by the first it cannot secure identical treatment under the clause unless the treaty-making power considers the second sacrifice actually equal to the first.

This ground was further emphasized in the subsequent negotiations with Switzerland, Germany and other European powers. Under the authority of the Dingley act a reciprocity agreement between the United States and France was negotiated on May 30, 1898. On June 29th, Mr. Pioda, the Swiss minister at Washington, demanded that the same privileges be extended to Swiss products, on the ground that the terms of the Swiss treaty of 1850 expressly

${ }^{1}$ Bertram et al. v8. Robertson, Collectors of the Port of New York, U. \$. Sup. Ct. Report, Vol. 122.

3oote, International Law Digest, Vol. V, pages 277-83. 
covered the case. Article IX of that treaty stated that neither party should "impose any higher... duties upon . . . the . . . products of the other . . . than shall be payable upon the like articles being the produce of any other country."

It was found upon examining the correspondence attending the negotiation of the Swiss treaty that a consideration of the intent of the negotiators required that the United States adopt the Swiss view as to its meaning. At the same time the statement was made that the Swiss agreement must be considered "as henceforth constituting an exception to the otherwise uniform policy of the United States." The customs officials were therefore instructed to grant the same terms to Swiss products that had been granted to those of France. The United States insisted, however, that it might prove necessary for her to denounce the treaty under which she was obliged to adopt this agreement, since it was clearly in opposition to our well-established practice.

This yielding to the Swiss claims was at once followed by claims from other governments that they should be granted the same privilege which had been gratuitously granted to Switzerland. To accede to these requests would be equivalent to giving freely to all nations the concessions made to France. To avoid this consequence, notice was given to Switzerland that the United States would terminate its convention of 1850 so far as the articles in question were concerned at the end of one year. The denouncement of the articles finally took effect March 23, 1900.

The same French agreement which had brought this complication with Switzerland aroused the Germans to insist that they must be put upon the same basis by virtue of the treaty of the United States with Prussia of the date of 1828 . Investigation of the terms of the convention showed, however, that Germany's grievances were based only upon the prevailing difference of opinion as to the application of the "most favored nation" clause to reciprocity treaties, and the claim was disallowed.

\section{Application of the Clause to Laws of Congress}

Besides the application of the "most favored nation" clause to treaties there are two other general classes of cases in which it has been invoked. These involve the application of our laws of 
Congress to foreign trade. They may be grouped under: (I) geographical discriminations, and (2) retaliatory discriminations.

Geographical Discriminations.-On June 26, I884, an act went into force "to remove certain burdens on the American merchant marine, and encourage the American foreign carrying trade." Section fourteen of this law provided a modification of the tonnage duties which had been re-enacted at the time of the Civil War. It granted to vessels entering the ports of the United States from ports of Central and South America a tonnage reduction of one-half of the amount charged other ships. Each such vessel was to pay three cents per ton-not to exceed fifteen cents in any one year, instead of six cents-not to exceed thirty cents in any one year, the rate charged to others. Belgium, Denmark, Germany, Italy, Portugal, Sweden and Norway protested against the enforcement of this law on the ground that it violated their treaty rights. The argument presented by Germany is fairly typical of the others. It was maintained that the answer made by the United States that the discrimination was purely geographical in character was unsatisfactory. If this principle was admitted it might make all "most favored nation" guarantees of no value. Geographical discrimination might be used to the extent of excluding-for example-all but Germany. Even if such exceptional laws could be justified in certain restricted cases where the countries were contiguous they could not be so when countries at a distance were involved. In effect, if not in wording, the act, it was claimed, violated the treaty agreements.

In I886, with the protests still unsatisfied, another act was passed authorizing the President to extend the favorable tonnage regulations to all parts of South America. In addition the President was authorized to extend similar privileges to any other country upon the assurance that no higher duties were charged American vessels in the ports of such country. To this interpretation Germany again objected, because not only was the act of 1884 not repealed, but was extended to include South America.

"The original attitude assumed by the German government towards the old law has been in no wise changed by the new act. . . As long as vessels from the ports of North and Central America pay but one-half of the tonnage duty that is levied upon vessels from German ports without being required to furnish proof that less than six cents is exacted from American 
vessels in their ports, the imperial government will be obliged to maintain its claim for similar usage. ${ }^{3}$

The United States has not seen fit to modify its holdings as to its right to make geographical discriminations. Our policy is to abolish tonnage duties as against countries which do the same for us. In but few countries, however, is there an absence of tonnage duties of some sort, and consequently the law has had a negligible effect in practice.

Retaliatory Discriminations. Clauses providing for retaliations against unfair trade conditions introduced by other countries are to be found in the McKinley act of October I, I890, the tariff act of August 28, I894, and the act of July 24, 1897. In all these cases the interpretation of the "most favored nation" clause has been involved.

Under the McKinley act it was provided that when the President should be satisfied that any country producing and exporting sugars, molasses, coffee, tea and hides, or any of such articles imposed duties on the products of the United States which were unfair in view of the free importation into the United States of the enumerated articles, he should suspend such free importation and place upon the articles certain duties. Under this power a proclamation was issued March I5, I892, imposing duties on the specified articles when imported from Colombia. Colombia protested to the United States, but it was maintained that the law was no violation of the "most favored nation" guarantee since it applied "the same treatment to all countries whose tariffs are found by the President to be unequal and unreasonable."

One of the most interesting phases of the discussion of the "most favored nation" clause is that raised by the payment of bounties for exportation. Where a bounty is paid for the exportation of certain domestic products does that introduce a discrimination in trade which a foreign country may counteract by increasing its tariff on bounty-fed imports and still hold that it has not violated the "most favored nation" guarantee? As to this class of discriminations the division of authority is different from that as to the application of the clatse to reciprocity treaties. England and the United States are the leading advocates supporting such retaliatory

${ }^{3}$ Report of Mr. Bayard, Secretary of State, to the President, Jan. 14, 1889, H. Ex. Doc. 74, 50th Congress, 2d session. 
legislation. Russia, Germany, Austria-Hungary and the continental countries in general, stand opposed. This question has arisen under the tariff act of August 28, 1894, and the act of July 24, I897. Against the first act the German ambassador protested October 12, 1894, claiming that the German export tax on sugar which the act in effect counteracted by the levy of an additional duty of one-tenth of a cent a pound, was a domestic measure purely, and therefore outside the consideration of the United States. To enforce the law would, he said, deny to Germany the "most favored nation" treatment. In this contention Mr. Gresham, the then Secretary of State, was disposed to agree. ${ }^{4} \mathrm{Mr}$. Olney, who succeeded to the position in the following month, November, took the opposite view, holding that "the export sugar bounty of one country might be counteracted by the import sugar bounty of another without causing any discrimination which could be deemed a violation of the 'most favored nation' clause."'

This is the position finally assumed by the United States. The act of July 24, I897, further extended this principle by providing that any sugar imported from a country remitting the tax usually levied on all exported sugar, should be liable to an increased duty to the full amount of the refunded tax. Such repayment of taxes is, the courts have decided, only a disguised form of bounty. ${ }^{\circ}$

From what has preceded it is clearly seen that the "most favored nation" principle, as interpreted by the United States, has often been fruitful of misunderstanding if not of ill-will on the part of European countries. The treaty-making power of the United States, indeed, has often had to bear harsh criticism by foreign public opinion on other accounts also. In countries whose foreign offices can, by their own acts, bind the governments to treaty provisions without the concurrence of any other body, a constitutional requirement that after negotiation all treaties must be reviewed by the upper branch of the legislature is not easily understood. The part of the Senate in our foreign relations has not, indeed, been without serious criticism from many even in our own country. On the one hand it is asserted our government reserves to itself the privilege of retreating from a bad bargain, or one which does not

4Forelgn Relations, 1894, 236.

s21 Op. Atty. Gen, 80-82.

Downs vs. United States (1903), 187 U. s. 496. 
meet popular favor after the other party to the agreement has practically bound itself to all the treaty provisions—only the formal exchange of ratifications being left to be accomplished. This, it is claimed, introduces an unequal element into the negotiations.

On the other hand, it is argued that reference to the Senate denies mobility to our treaty-making machinery. The necessity of review by this body, with the attendant clash of party interests and the ever-present possibility of filibustering, surrounds the negotiations with so many possibilities of defeat that our government is at a distinct disadvantage in comparison with others.

The "most favored nation" clause as an element in our treaties has in the same way been a subject of criticism. Like the treaty. making power in general, it has often provoked resentment in foreign courts. This is due to no lack of consistency on the part of our government, but to a non-appreciation of the extent to which the United States intends to bind itself in the negotiations in question.

\section{The Advantage of the American Interpretation.}

The meaning of the clause has the distinct gain of giving flexibility in one respect in spite of our cumbersome treaty-making machinery. When the government in designing reciprocity agreements or commercial legislation can act with the assurance that the measure will apply only to that portion of our foreign trade which it is intended to affect, it is much easier to fit the legislation to needs than it is when it must constantly be borne in mind that the identical concessions may be claimed by other countries to which they were not intended to apply. The complexity of modern trade relations makes the application of an invariable rule often a means of introducing rather than eliminating discriminations. Indeed, in many cases a reciprocity treaty might provide for mutual concessions which, while not amounting to discrimination such as would violate the most favored nation principle, would be entirely destroyed in value were similar rights granted to others.

Take for example the Hawaiian treaty of 1875 , in which, among other things, it was agreed that that government should not during the life of the treaty lease any port, harbor or territory to any other power, or allow any other nation to obtain the privileges in customs duties which were granted to the United States. In 
return the United States granted certain commercial privileges to Hawaii. This agreement, the United States could maintain under its interpretation, was no violation of the most favored nation guarantee but was an adjustment which, though it gave exclusive privileges, was one which was justified by our peculiar relation to the islands. If the European interpretation of the clause had been strictly applied, it would have necessitated the disregard of all the local conditions which counseled special arrangements, with the result that the advantages which each of the powers sought by the agreement would have been minimized, if not destroyed.

A similar illustration is afforded by the Cuban reciprocity treaty of I903, granting to Cuban sugar a reduction of twenty per cent of the usual tariff in return for other concessions by Cuba. Cuba, it was further agreed, should continue during the life of the treaty to be the only country to whose sugar this advantage should be given. The peculiar political relations of the two countries, the United States held, justified its making such an agreement, notwithstanding its treaty guarantees to other nations. Not to allow the treaty-making power this freedom of action would indeed often hamper, if not destroy, its power to make the agreements demanded by actual conditions.

As applied both to treaty-making and legislation in general, the interpretation of the "most favored nation" clause adopted by the United States has the decided advantages of flexibility and certainty. It allows the adjustment of relations to varying conditions and thus avoids the adoption of uniform rules which in many cases would in fact amount to discrimination. It also avoids the uncertainty on the part of legislators and the courts which must of necessity be present when, due to the interlocking of the provisions of various treaties, it is not clear to what body of facts any law or treaty may apply. 